\title{
PENGUJIAN KINERJA PENCARIAN DATA
}

\author{
Yulia Agustina Dalimunthe \\ Staf Pengajar Sistem Informasi STT-Harapan \\ E-mail: Yuliaagustina_dalimunthe@yahoo.co.id
}

\begin{abstract}
The database is already a mandatory requirement for program makers in designing an application relating to records or transactions that require continuous data, the database is used as a data center that can be used to take out a policy in the future. Database must consider many factors ranging from storage, security, ease of accessing the database, the database selection of many factors used speed is the most important factor in the selection of database. PostgreSQL and MySQL is a database that is widely used to store data, the database is usually combined with programming language that is easy to use ENTER to store panin formations. Postgresql and Mysql database will be made based on the speed and search from the corresponding tables in each database.
\end{abstract}

Keywords: Database, PostgreSQL, MySQL.

\begin{abstract}
Abstrak
Database sudah merupakan kebutuhan wajib bagi para pembuat program dalam merancang suatu aplikasi yang berkaitan dengan record-record atau pun transaksi yang membutuhkan data yang berkelanjutan, database digunakan sebagai pusat data yang bias digunakan untuk mengambil suatu kebijakan kedepannya.Pemilihan database tentunya mempertimbangkan banyak factor mulai dari kapasitas penyimpanan, keamanan, kemudahan pengaksesan database, dari banyak factor pemilihan database yang digunakan kecepatan merupakan faktor yang paling utama dalam pemilihan database.PostgreSQL dan MySQL merupakan database yang banyak digunakan untuk menyimpan data, database tersebut biasanya dikombinasikan dengan bahasa pemrograman sehingga mudah digunakan untuk menyim panin formasi yang di inginkan.Pengujian database Postgresql dan Mysql akan dilakukan berdasarkan kecepatan dan pencarian data dari tabel yang sesuai di masing-masing database.
\end{abstract}

Kata Kunci: Database, PostgreSQL, MySQL.

\section{Pendahuluan}

Database atau juga sering disebut sebagai basis data adalah kumpulan dari item-item data yang saling berhubungan satu dengan lainnya yang diorganisasikan berdasarkan sebuah skema atau struktur tertentu, tersimpan dihardware komputer dan dengan software untuk melakukan manipulasi untuk kegunaan tertentu (Dewi Kusumawati, 2015).

Database adalah suatu aplikasi yang menyimpan sekumpulan data untuk membuat, mengakses, mengatur, mencari, dan menyalin data yang ada didalamnya(Gregorius Agung, 2014).

Database adalah kumpulan informasi yang terorganisasi dan disajikan untuk tujuan khusus. Basis data terkomputerisasi dapat di up-date, file bisa terorganisasi, dan informasi dapat dibaca, dicari dengan cepat, dan di retrieve menggunakan komputer (Tominanto, 2013).

Softwareuntuk melakukan manipulasi pada database disebut dengan Database Management System (DBMS) (Dewi Kusumawati, 2015).

DBMS adalah bagian perangkat lunak yang didesain untuk mempermudah pekerjaan dalam pengolahan data. Dengan penyimpanan data ke dalam suatu DBMS, akan lebih mudah daripada menyimpannya ke dalam sistem file. DBMS dapat digunakan untuk mengolah data secara efisien (Tominanto, 2013).

Banyaknya database yang beredar di pasaran membuat banyak programmer bebas memilih jenis database yang bisa dipergunakan untuk membuat program aplikasi database, tetapi dari sekian banyak database yang beredar, ada beberapa database yang merupakan database favorit yang banyak dipergunakan oleh software developer beberapa diantaranya adalah MySQL, Microsoft SQL Server, SQLite, Microsoft Access, dan PostgreSQL untuk pembahasan pada tugas akhir ini penulis menggunakan database MySQL dan PostgreSQL( Gregorius Agung, 2014).

\section{PostgresSQL}

PostgreSQL atau disebut Postgres merupakan salah satu dari sekian banyak database besar yang ada, yang menawarkan skalabilitas, keluwesan, dan kinerja yang tinggi bagi user. 
Postgres pertama kali muncul pada tahun 1996.PostgresSQL merupakan database server untuk mengolah data yang bersifat open source, dan memiliki lisensi GPL (General Public License) serta merupakan salah satu dari sekian banyak database server yang ada.

Postgres adalah ORDBMS (Object Relational Database Management System) yang bersifat open source(Dewi Kusumawati, 2015).

Beberapa fitur PostgreSQL adalah sebagai berikut :

1. Inheritance, dimana satu table dapat diturunkan model dan beberapa karakteristik dari table lainnya.

2. Multi Version Concurrency Control (MVCC), dimana user diberi data snapshot ketika suatu perubahan dilakukan sampai commit.

3. Rules, dimana suatu query DML yang dikirimkan ke serverakan mengalami penulisan ulang (rewrite). Ini terjadi sebelum diproses lebih lanjut oleh query planner.

4. Dan berbagai fitur lainnya. Adapun beberapa kelebihan yang dimiliki PostgreSQL adalah sebagai berikut:

1. Forking (arsitektur multiproses) yang dimana memiliki kestabilan yang tinggi.

2. Dalam kondisi load tinggi (jumlah koneksi simultan yang besar) yang dimana PostgreSQL mendukung locking dilevel rendah.

3. Memiliki fitur $O O$ yang dimana $O O$ ini seperti pewarisan tabel dan tipe data, mendefenisikan sebuah tabel yang mewarisi defenisi tabel lain.

4. Menyedikan hampir semua fitur-fitur dalam pengolahan database.

5. Memiliki tipe data geometri seperti : titik, garis, poligon, lingkaran.

6. Memiliki kemampuan mendefenisikan field sebagai array.

7. Memiliki hampir semua fasilitas standar yang biasa diinginkan.

8. Memiliki rule yang dimana tindakan custom saat dieksekusi bisa didefenisikan saat tabel di insert,update, ataupun delete.

9. Memiliki kemampuan konektifitas pada database dan hampir semua database pada Linux.

10. Memiliki kemampuan menampung data spasial, sehingga bisa digunakandalam pembuatan situs berbasis Web GIS.

11. Memiliki lisensi GPL(General Public License) didistribusikan secara gratis.

12. Mendukung banyak jenis bahasa pemrograman.

13. Alternatif bagi sistem data open sourcelain seperti MySQL.

PostgreSQL merupakan salah satu DBMS yang digunakan untuk menyimpan data dan bersifat open source.Untuk dapat menyimpan data spasial, PostgreSQL membutuhkan plugin tambahan yaitu PostGIS.
Tipe data PostGreSQL antara lain:

1. numerik (integer dan numeric).

2. string atau teks (char dan VarChar).

3. interval.

4. timestamp.

5. date.

Selain itu PostGreSQL juga menyediakan tipe data geometrik terutama dalam kaitannya untuk PostGIS dan byte (Nasytha Nur, et al, 2014).

\section{MySQL}

My Structured Query Language (MySQL) adalah perangkat lunak sistem manajemen basis data SQL atau DBMS yang multithtread, multiuser, dengan sekitar 6 juta instalasi di seluruh dunia. MySQL tersedia sebagai perangkat lunak gratis dibawah lisensi (GPL)General Public License(Tominanto, 2013).

MySQL memiliki beberapa keistimewaan, antara lain :

1. Portabilitas yang dimana MySQL dapat berjalan stabil pada berbagai sistem operasi seperti Windows, Linux, dan masih banyak lagi.

2. Memiliki lisensi GPL(General Public License) didistribusikan secara gratis.

3. Multi-userdimana MySQL dapat digunakan oleh beberapa pengguna dalam waktu yang bersamaan.

4. Memiliki performance tuning dimana memiliki kecepatan yang menakjubkan dalam menangani query sederhana, dengan kata lain dapat memproses lebih banyak SQL per satuan waktu.

5. Memiliki beragam tipe data seperti signed / unsigned integer, float, double, char, text, date, timestamp, dan lain-lain.

6. Memilikioperator dan fungsi secara penuh yang mendukung perintah Select dan Where dalam perintah (query).

7. Memiliki beberapa lapisan keamanan seperti level subnetmask, namahost, dan izin akses user dengan sistem perizinan yang mendetail serta sandi terenkripsi.

8. Memiliki kemampuan menangani basis data dalam skala besar, dengan jumlah rekaman (records) lebih dari 50 juta dan 60 ribu tabel serta 5 miliar baris. Selain itu batas indeks yang dapat ditampung mencapai 32 indeks pada tiap tabelnya.

9. MySQL menggunakan protokol TCP/IP, Unix soket (UNIX), atau Named Pipes (NT) dalam melakukan koneksifitas.

10. MySQL memiliki lebih dari dua puluh bahasa dalam mendeteksi pesan kesalahan dapat mendeteksi pesan kesalahan, meski pun demikian, bahasa Indonesia belum termasuk di dalamnya.

11. Memilikiantar muka (interface) terhadap berbagai aplikasi dan bahasa pemrograman dengan menggunakan fungsi API (Application Programming Interface). 
12. Dilengkapi dengan berbagai peralatan (tool)yang dapat digunakan untuk administrasi basis data.

13. Memilikistruktur tabel yang lebih fleksibel dalam menangani ALTER TABLE, dibandingkan basis data lainnya semacam PostgreSQL ataupun Oracle (Rivaldi Masuara, 2015).

Kemampuan lain yang dimiliki MySQL adalah mampu mendukung Relasional Database Manajemen System (RDBMS), sehingga dengan kemampuan ini MySQL akan mampu menangani data-data sebuah perusahaan yang berukuran sangat besar hingga berukuran Giga Byte(Tominanto, 2013).

MySQL adalah RDBMS yang cepat dan mudah digunakan, serta sudah banyak digunakan untuk berbagai kebutuhan (Gregorius Agung, 2014).

hal-hal yang membuat MySQL populer :

1. berlisensiopen source, sehingga penggunaan secara gatis.

2. Program yang powerfull dan menyediakan fitur yang lengkap.

3. Berbentuk standar bahasa data SQL.

4. Bekerja dengan baik dengan sistem operasi lain seperti bahasa pemograman PHP, PERL, C, C++, dan lain-lain.

5. Bekerja dengan baik bahkan dengan data set yang banyak.

6. Mendukung banyak database, sampai 50 juta baris atau lebih dalam suatu table.

\section{Metode Pencarian Data}

Pengujian kinerja database MySQL dan PostgreSQL pada sistem yang dirancang penulis hanya berdasarkan waktu atau biasa disebut dengan execution time. Pengujian dilakukan menggunakan 2 (dua) database yang berbeda dan tentunya memiliki struktur database yang berbeda baik dari cari pengaksesan dan koneksinya, untuk memudahkan pengujian dibuat beberapa aturan sehingga pengujian akan lebih mudah dilakukan, beberapa aturannya adalah sebagai berikut :

1. Masing-masing memiliki sebuah database dengan nama harapan.

2. Tabel pada database harapan diberi nama tabel uji yang memiliki sebuah field nama denga tipe char ukuran 100

3. Field pada tabel tidak memiliki primary key dan index key.

4. Record yang disimpan sebanyak 20 karakter dengan kombinasi huruf besar, huruf kecil dan angka.

5. Record yang disimpan dihasilkan dari proses pengambilan file text yang berisi karakter acak dengan setiap barisnya terdiri dari 20 karakter.

6. Konektivitas ke service database menggunakan ODBC sehingga pengaturan koneksi ke MySQL ataupun PostgreSQL dilakukan di OBDC.
7. Koneksi yang dilakukan pada visual basic.net 2010 menggunakan ADODB untuk MySQL dan PostgreSQL.

Aturan ataupun kondisi dari pengujian tersebut akan diterapkan pada sistem yang dirancang, untuk pengujian kecepatan baik dari proses penyisipan dan pencarian pesan dapat diliat dari tabel jumlah record dibawah ini :

Tabel 1. Jumlah dan Waktu Pengujian Penyisipan

\begin{tabular}{|c|c|c|c|c|c|c|c|}
\hline Dilabicie & 10: & 150 & 500 & $7 \%$ & 100 & $510 \%$ & $.(0))$ \\
\hline \multirow[t]{2}{*}{ 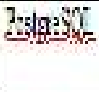 } & 3.5 & 14. & $12 \%$ & 40.0 & 413 & 26.88 地 & 4.43 \\
\hline & 些: & 恙 & 柆: & 掉: & 望 & & di \\
\hline \multirow[t]{2}{*}{ M/SWLL } & 6.27 & 150 & $30 \%$ & & 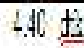 & 3.1. & $33 \ldots\}$ \\
\hline & 些: & 些 & 拉: & 拈: & & d & $d$ \\
\hline
\end{tabular}

Tabel diatas merupakan hasil pengujian yang dilakukan secara manual dengan menggunakan perintah insert didalam database PostgreSQL dan MySQL, perintah dijalankan pada query editor bawaan PostgreSQL dan sedangkan MySQL digunakan software navicat sebagai software tambahan untuk management database MySQL.

Waktu eksekusi dari tabel penyisipan diatas berbeda untuk setiap komputer dan bergantung kepada processor dan memori yang tersedia, analisa berikutnya adalah pencarian data atau record yang ada didalam tabel. Untuk pencarian data dikarenakan data yang dimiliki oleh masing-masing tabel belum tentu sama maka pencarian akan dilakukan berdasarkan kemiripan karakter yang ada didalam tabel PostgreSQL maupun MySQL, berikut hasil pencariannya dengan jumlah huruf 2 karakter sampai dengan 4 karakter dengan record yang ada didalam tabel sebanyak 100000 record.

Tabel 2 Waktu Pengujian Pencarian

\begin{tabular}{|c|c|c|c|c|}
\hline Je:abie & $A 3_{2} \cdots$ & $2 \mathrm{Ka} 2 \mathrm{de}$ & 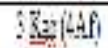 & 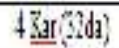 \\
\hline \multirow[t]{2}{*}{ Postrivi } & \multirow[t]{2}{*}{7064} & $014 \pm$ & $010 \mathrm{dz}$ & 669 \\
\hline & & 2ust = ? & 3 3at $=12$ & R:3int $=\mid 3 i$ \\
\hline \multirow[t]{2}{*}{ KGSOL } & \multirow[t]{2}{*}{$638 \mathrm{dt}$} & $0 \div \leqslant$ & $010 \underline{\mathrm{d}}$ & 018 \\
\hline & & Pesult $=26$ & Resir $=76$ & $3 \mathrm{E} x \mathrm{t}=16 ?$ \\
\hline
\end{tabular}

Pengujian pencarian dilakukan dengan menggunakan SQL Query PostgreSQL dan navicat, waktu hasil pencarian juga bisa berbeda tergantung kecepatan processor dan memori yang digunakan.

Perancangan sistem merupakan gambaran dari sistem yang akan dibuat dalam hal ini adalah aplikasi pengujian kecepatan database PostgreSQL dan MySQL dalam hal penyisipan dan pencarian.

Use case class digunakan untuk memodelkan dan menyatakan unit fungsi/layanan yang disediakan oleh sistem (or bagian sistem : subsistem atau class) ke pemakai, berikut adalah use case diagram yang 
penulis untuk memodelkan sistem yang akan dirancang :

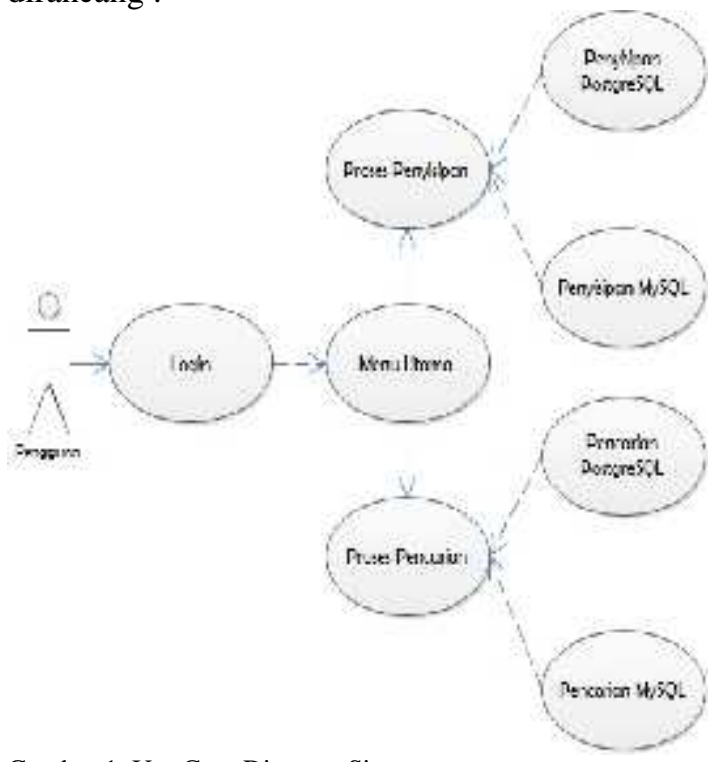

Gambar 1. Use Case Diagram Sistem

Class diagram digunakan untuk menampilkan kelas-kelas dan paket-paket di dalam sistem. Class diagram memberikan gambaran sistem secara statis dan relasi antar mereka. Biasanya, dibuat beberapa class diagram untuk sistem tunggal. Beberapa diagram akan menampilkan subset dari kelas-kelas dan relasinya. Dapat dibuat beberapa diagram sesuai dengan yang diinginkan untuk mendapatkan gambaran lengkap terhadap sistem yang dibangun.

Class diagram adalah alat perancangan terbaik untuk tim pengembang. Diagram tersebut membantu pengembang mendapatkan struktur sistem sebelum kode ditulis, dan membantu untuk memastikan bahwa sistem adalah desain terbaik, berikut adalah class diagram dari aplikasi yang dirancang :

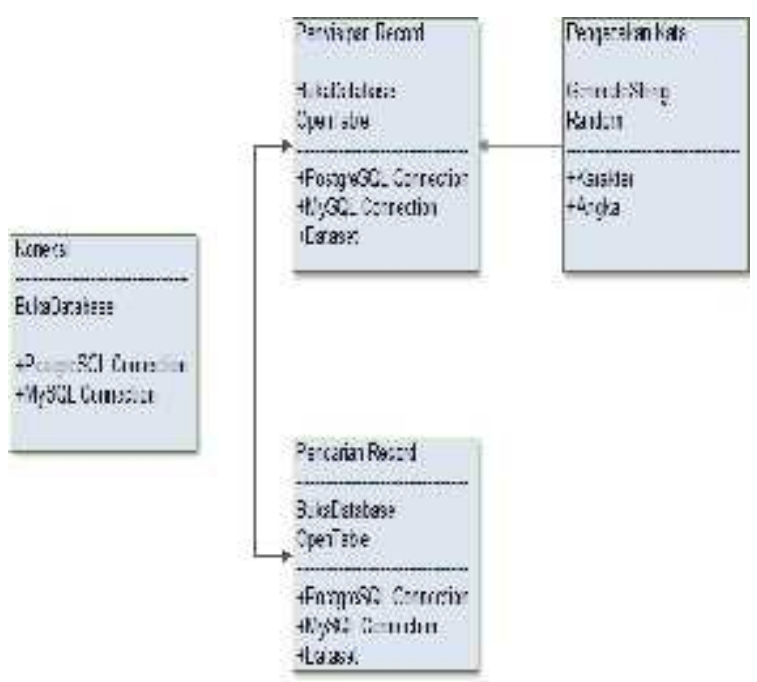

Gambar 2. Class Diagram Sistem

Perancangan program digunakan untuk menggambarkan desain dari program yang akan dirancang, pada aplikasi ini terdiri dari 5 (lima) buah form yang bisa digunakan dimulai dari form login sampai dengan form tentang penulis, berikut adalah rancangannya :

1. Desain Form Login

Desain Form login merupakan desain dari sistem yang digunakan sebagai security form bagi pengguna sistem, berikut adalah desain dari sistem yang dirancang :

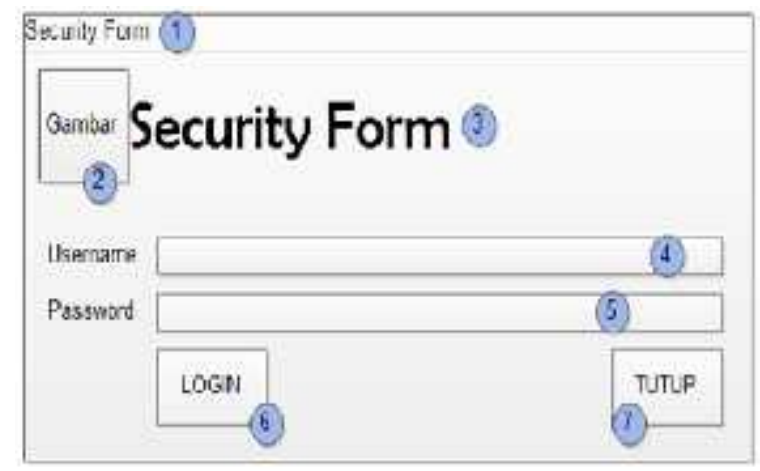

Gambar 3. Desain Form Login

Adapun keterangannya sebagai berikut :

1. Judul dari form yang dirancang.

2. Menampilkan gambar icon dari form yang dirancang.

3. Judul dari form.

4. Textbox yang digunakan untuk memasukkan username.

5. Textbox yang digunakan untuk memasukkan password.

6. Tombol untuk login berdasarkan username dan password.

7. Tombol untuk keluar dari aplikasi.

2. Desain Form Utama

Desain form utama merupakan desain dari form utama yang digunakan untuk memanggil form yang ada, berikut adalah desain dari form utama yang dirancang:

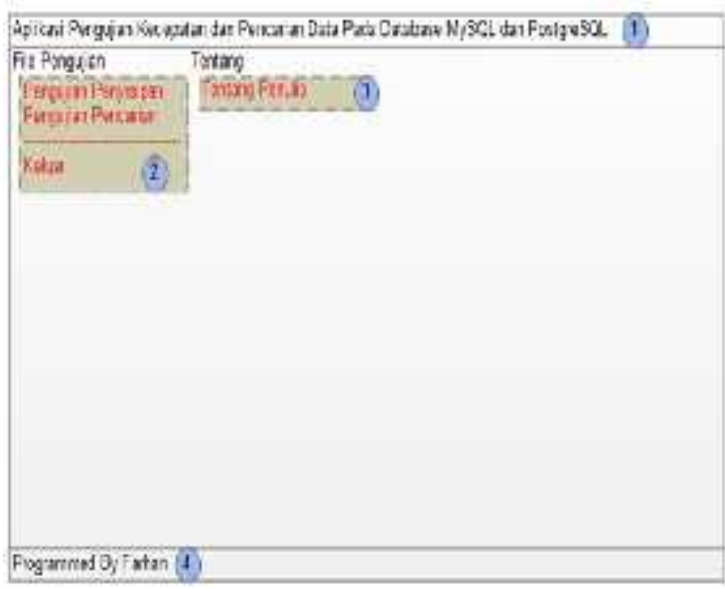

Gambar 4. Desain Form Utama

Adapun keterangannya sebagai berikut :

1. Judul dari form utama yang dirancang. 
2. Menu file pengujian yang terdiri dari :

a. Pengujian Penyisipan Pengujian penyisipan digunakan untuk memanggil form pengujian penyisipan database.

b. Pengujian Pencarian Pengujian pencarian digunakan untuk memanggil form pengujian pencarian pada database.

c. Keluar

Sub menu yang digunakan untuk keluar dari aplikasi.

3. Menu file tentang yang digunakan untuk menampilkan informasi mengenai penulis.

4. Statusbar yang digunakan untuk menampilkan informasi nama penulis.

3. Desain Form Pengujian Penyisipan Record Desain form pengujian penyisipan record merupakan desain yang digunakan untuk menguji kecepatan penyisipan record kedalam database MySQL dan PostgreSQL, berikut adalah desainnya :

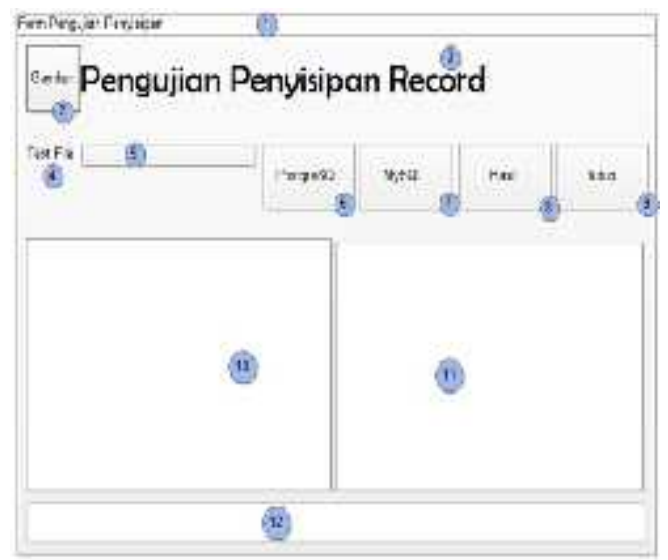

Gambar 5. Desain Form Penyisipan Record

Adapun keterangannya sebagai berikut :

1. Title dari form utama yang dirancang.

2. Menampilkan icon dari form yang dirancang.

3. Menampilkan teks dari form.

4. Label informasi lokasi file text.

5. Textbox yang digunakan untuk menentukan lokasi file text yang berisi karakter acak yang akan disimpan didalam database MySQL ataupun PostgreSQL.

6. Tombol postgreSQL digunakan untuk memproses record sebanyak nilai yang ada didalam textbox dengan output berupa lama waktu penyisipan.

7. Tombol MySQL digunakan untuk memproses record sebanyak nilai yang ada didalam textbox dengan output berupa lama waktu penyisipan.

8. Tombol yang digunakan untuk menampilkan hasil perbandingan waktu penyisipan dengan PostgreSQL dan MySQL.

9. Tombol yang digunakan untuk menutup form.
10. Textbox yang digunakan untuk menampilkan informasi record yang disisipkan dengan menggunakan database PostgreSQL.

11. Textbox yang digunakan untuk menampilkan informasi record yang disisipkan dengan menggunakan database MySQL.

12. Textbox yang digunakan untuk menampilkan informasi hasil penyisipan postgreSQL dan MySQL.

4. Desain Form Pengujian Pencarian Record Desain form pengujian pencarian record merupakan desain yang digunakan untuk menguji kecepatan pencarian record dari database MySQL dan PostgreSQL, berikut adalah desainnya :

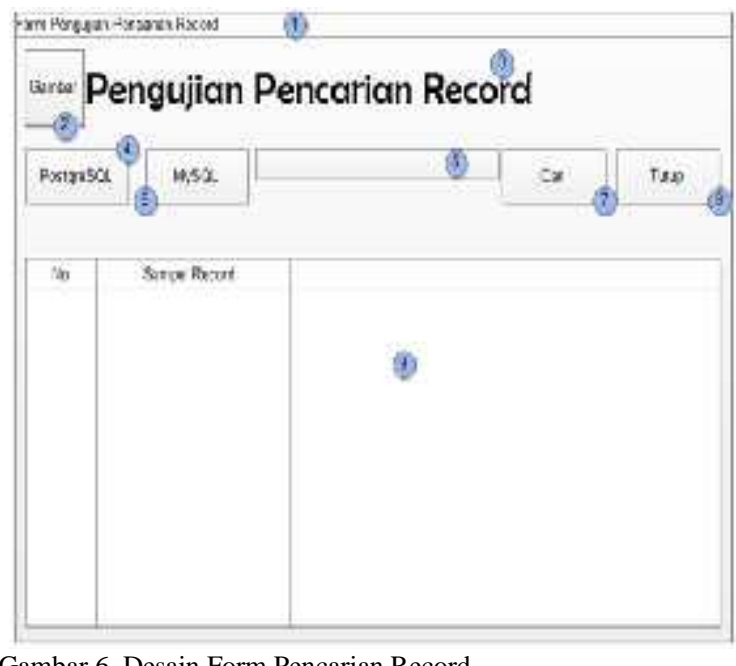

Gambar 6. Desain Form Pencarian Record

Adapun keterangannya sebagai berikut:

1. Title dari form utama yang dirancang.

2. Menampilkan icon dari form yang dirancang.

3. Menampilkan teks dari form.

4. Tombol PostgreSQL digunakan untuk menampilkan seluruh record yang ada didalam tabel uji yang berada di database PostgreSQL.

5. Tombol MySQL digunakan untuk menampilkan seluruh record yang ada didalam tabel uji yang berada di database MySQL.

6. Textbox yang digunakan untuk memasukkan string yang akan dicari kedalam database MySQL ataupun PostgreSQL.

7. Tombol yang digunakan untuk mencari record berdasarkan string yang dimasukkan.

8. Tombol untuk menutup form.

9. Listview data yang digunakan sebagai media penampil informasi record yang akan ditampilkan.

5. Desain Form Tentang Penulis berikutnya adalah form tentang penulis berikut adalah desainnya : 


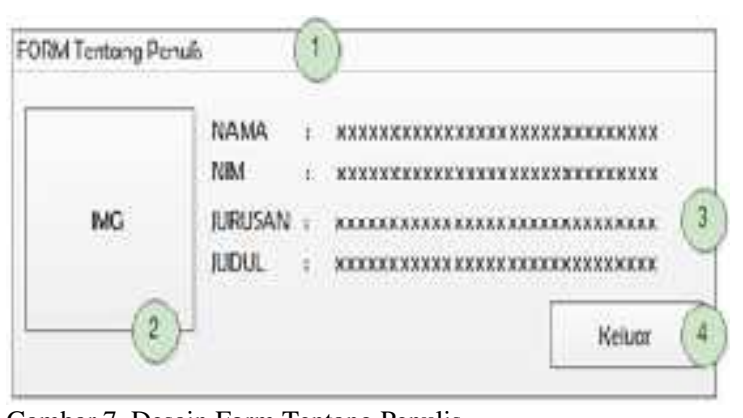

Gambar 7. Desain Form Tentang Penulis

Adapun keterangannya sebagai berikut :

1. Menampilkan title dari form tentang penulis.

2. Menampilkan gambar penulis.

3. Menampilkan informasi penulis.

4. Tombol keluar digunakan untuk menutup form tentang aplikasi.

\section{Hasil Penelitian}

Tampilan security form merupakan tampilan yang pertama kali muncul ketika aplikasi dijalankan (run). User harus mengisi username dan password sesuai dengan yang telah di defaultoleh user untuk dapat masuk ke sistem. Berikut gambar tampilan security form.

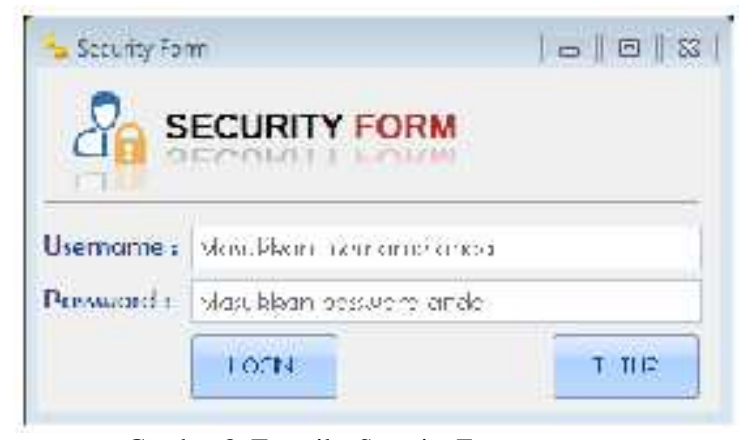

Gambar 8. TampilanSecurity Form

Gambar di atas merupakan security form dari aplikasi ketika dijalankan pertama sekali, pada sebutter dapat dua buah textbox yang digunakan untuk memasukkan user name dan password.Dan memiliki dua buah tombol yaitu tombollogin dan tutup, fungsi tombollogin untuk membuka tampilan program yang telah dibuat, sedangkan tombol tutup untuk menutup tampilan form awal program.

Ketika user selesai melakukan login, maka user akan memasuki form utama. Berikut tampilan form utama.

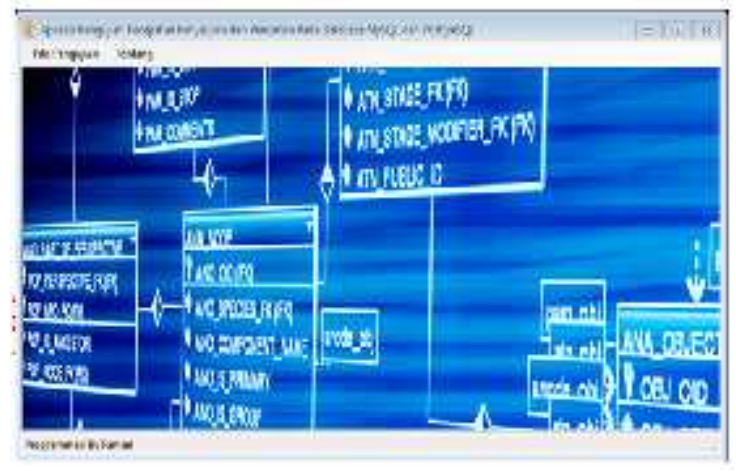

Gambar 9. TampilanFormUtama

Pada gambar di atas terdapat dua buah menu file yaitu тепи file pengujian dan тепи file tentang. Didalam menu file pengujian terdapat tiga sub menu file yang terdiri dari pengujian penyisipan, pengujian pencarian, dan keluar. Sub тепи Pengujian penyisipan digunakan untuk memanggil form pengujian penyisipan database, sиb тепи Pengujian pencarian digunakan untuk memanggil form pengujian penyarian database, dan sub menu keluar untuk keluar dari aplikasi.

Form penyisipan merupakan tampilan untuk user menyisipkan data yang telah dibua tsebelumnya yang nantinya akan diuji kecepatan penyisipannya sesuai dengan postgresql dan mysql yang telah ditetapkan. Berikut tampilan form penyisipan.

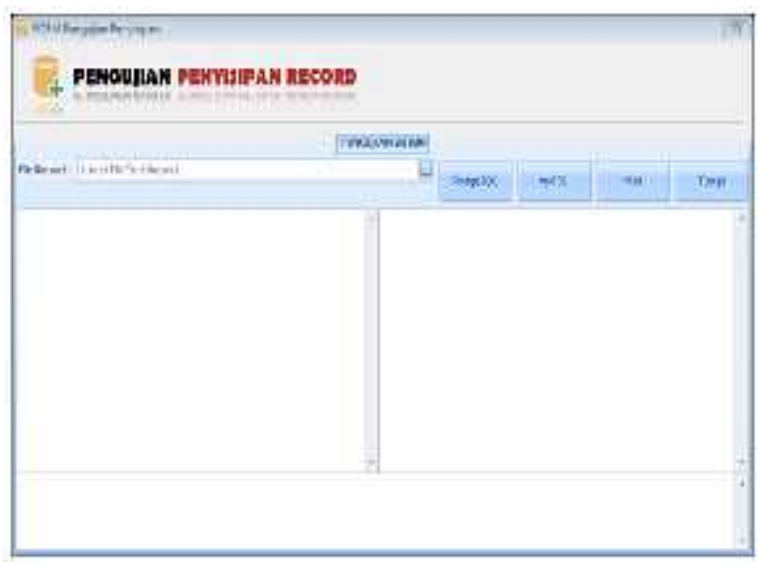

Gambar 10. TampilanFormPenyisipan

Pada gambar di atas terdapat dua buah text box yaitu text box untuk menentukan lokasi file text yang berisi jumlah record yang akan dimasukkan kedalam tabel yang ada di dalam database PostgreSQL dan MySQL, text box untuk menampilkan informasi record yang disisipkan pada database PostgreSQL, text box untuk menampilkan informasi record yang disisipkan pada database MySQL, dan textbox untukmenampilkan informasihasil penyisipan PostgreSQL dan MySQL .Selain itu pada gambar di atas memiliki empat buah tombol yaitu tombol postgre untuk memproses recordse banyak nilai yang ada didalam textbox dengan output berupa lama waktu penyisipan dalam PostgreSQL, tombol 
MySQL untuk memproses record sebanyak nilai yang ada di dalam textbox dengan output berupa lama waktu penyisipan dalam MySQL,tombol hasil untuk menampilkan hasil perbandingan waktu penyisipan dengan PostgreSQL dan MySQL, serta tombol tutup untuk menutup form.

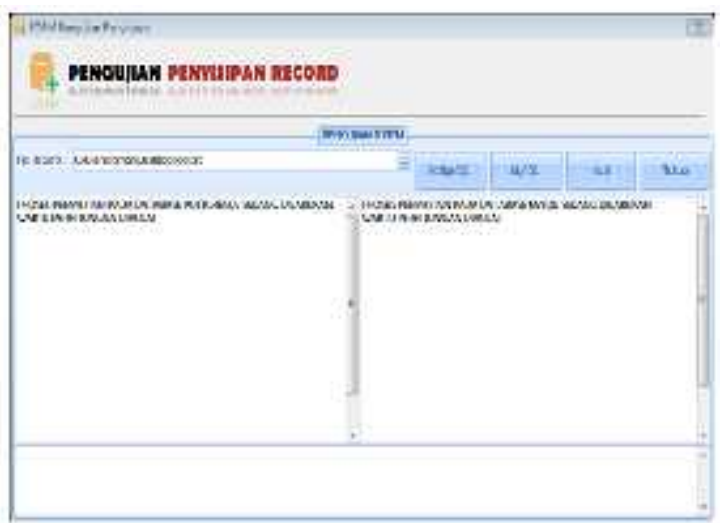

Gambar 11. TampilanProses PenyisipanBerjalan

Sebelumnya kita buat sebuah database terlebih dahulu sehingga database yang ingin kita buatter sebut akanm enjadi database yang akan kita uji. Dan pilih lokasi file text yang sudah kita buat untuk kita proses selanjutnya.

Pada Gambar 12 menampilkan proses penyisipan sedang berjalan, ketika proses penyisipan selesai maka akan muncul informasi sebagai berikut :

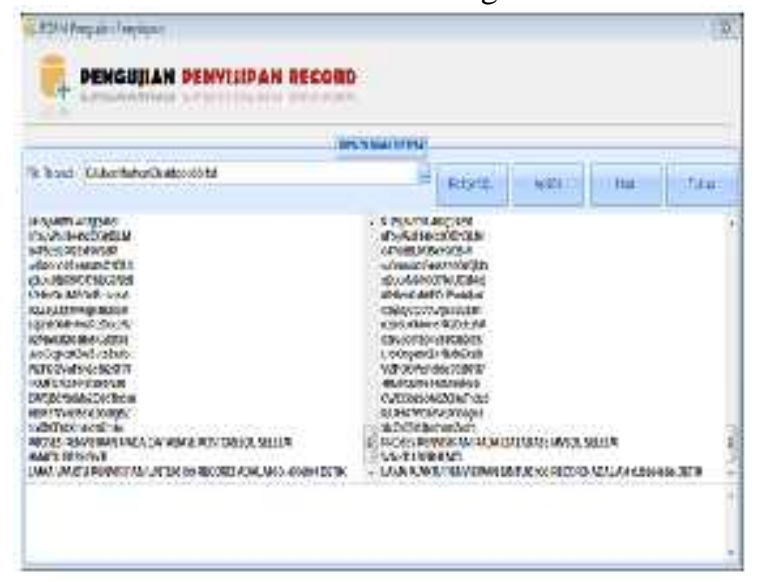

Gambar 12. Tampilan Proses PenyisipanSelesai

Proses penyisipan selesai dilakukan dengan jumlah record yang disisipkan sebanyak 100 record, dan membutuhkan waktu 0.56 detik dalam penyisipan MySQL, dan untuk PostgreSQL membutuhkan waktu 0.47 detik. Untuk melihat hasilnya berikut tampilannya :

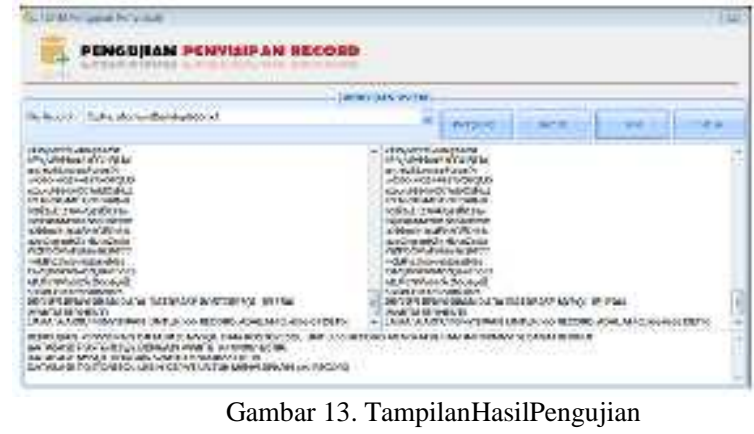

Untuk melihat penyisipan berhasil dilakukan dalam MySQL, maka dapat dilihat dalam form berikut.

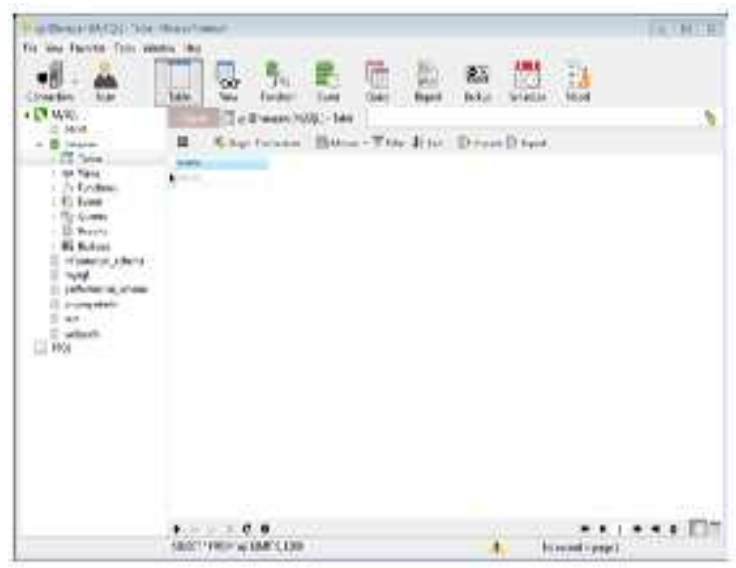

Gambar 14. TampilanForm MySQL

Pada Gambar 15 tampak bahwa table tersebut masih belum terisi, maka langsung saja kita klik tabel uji maka hasilnya sebagai berikut :

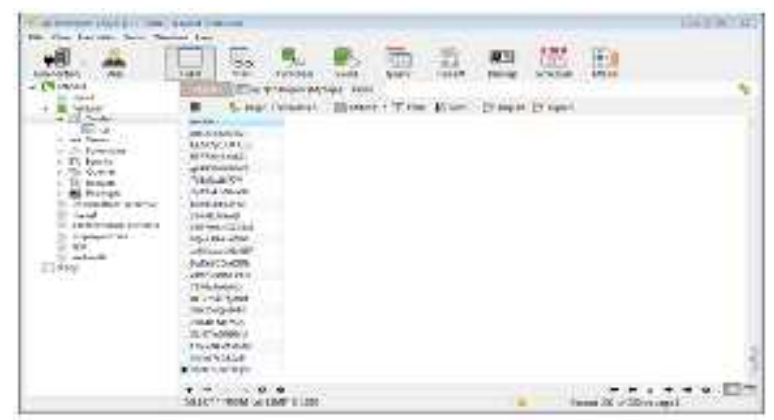

Gambar 15. TampilanForm MySQL BerhasilDisisipkan

Tampak bahwa record yang disisipkan dalam program berhasil masuk dalam tabel yang dibuat.

Form pencarian merupakan tampilan untuk user mencari data yang diambil dari data yang telah diberhasil disisipkan sebelumnya yang nantinya akan diuji kecepatan pencarian sesuai dengan postgresql dan mysql yang telah ditetapkan. Berikut tampilan form pencarian. 


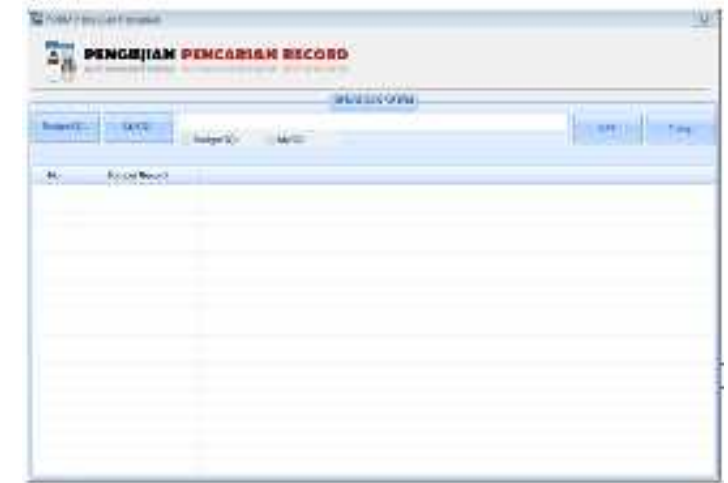

Gambar 16. TampilanFormPencarian

Pada Gambar 17 terdapat empat tombol yaitu tombol PostgreSQL untuk menampilkan seluruh record ada didalam tabel uji yang berada di database PostgreSQL, tombol MySQL untuk menampilka seluruh record ada di dalam tabel uji yang berada di database MySQL, tombol cari untuk mencari record berdasarkan string yang dimasukkan, dan tombol tutup untuk menutup form. Serta memiliki sebuah textbox untuk memasukkan string yang akan dicari kedalam database MySQL ataupun PostgreSQL. Dan juga memilikilistview yang digunakan sebagai media penampil informasi record yang akanditampilkan.

Sebelum melakukan pencarian record, terlebih dahulu kita tampilkan record yang telah disisipkan sebelumnya berikut adalah tampilannya:

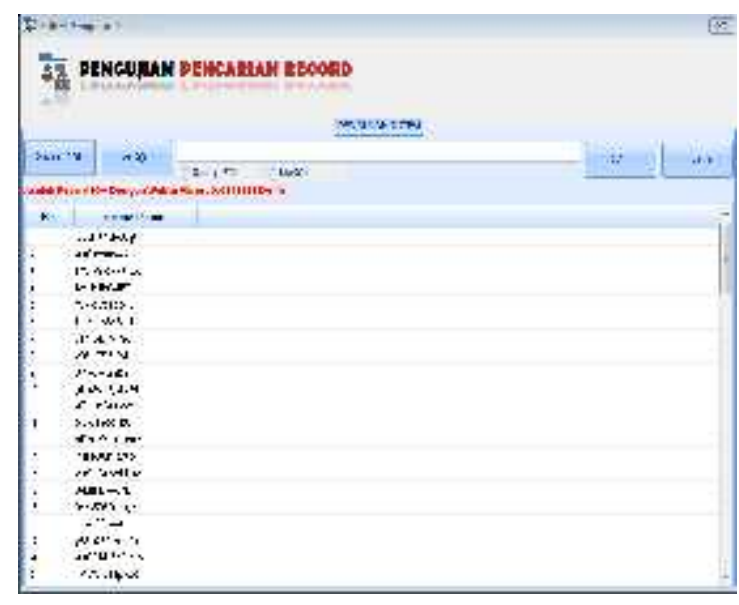

Gambar 17. TampilanForm Record

Selanjutnya kita masukkan string yang ingin kita cari yang ada didalam database tersebut.Disini saya akan mencari berdasarkan kemiripan dua karakter yaitu 48 denganrecord yang ada. Berikut tampilannya :

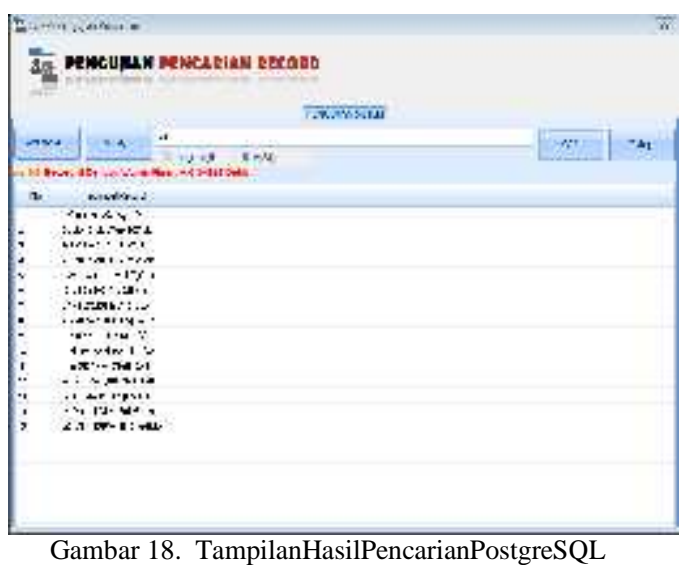

Berdasarkan gambar di atas bahwa pada proses pencarian pada PostgreSQL dengan menggunakan kemiripan dua karakter yaitu 48 memiliki jumlah empat buah record dengan kemiripan yang sama dan membutuhkan waktu 0.0035detik.Sedangkan untuk proses pencarian MySQL membutuhkanwaktu 0.0026 detik.

\section{Kesimpulan}

Dengan adanya perancagan aplikasi Pengujian Kinerja Penyisipan Dan Pencarian Data PadaPostgresql Dan Mysql, maka dapat ditarik kesimpulan sebagai berikut :

1. Aplikasi yang dirancang untuk menguji database pada Postgresql dan Mysql berdasarkan pengujian kecepatan penyisipan dan pencarian, agar menjadi sebuah informasi dalam menentukan pemilihan database berdasarkan factor kecepatannya. Walaupun demikian, hasil pengujian berpengaruh terhadap spesifikasihardware dan software yang digunakan.

2. Pengujian kinerja ini dapat digunakan untuk membantu dalam pemilihan database dalam hal kecepatan waktu berdasarkan records yang digunakan.

Berikut adalah beberapa saran untuk pengembangan lebih lanjut terhadap penelitian skripsi ini :

1. Perlu diadakan penilitian lebih lanjut pada Postgresql dan Mysql untuk mengetahui sensitifitas guna mendukung kecepatan pada hardware dan software yang digunakan.

2. Aplikasi pengujian kinerja ini dapat dikembangkan dengan menambahkan beberapa factor pemilihan database seperti kapasitas penyimpanan, keamanan, dan kemudahan dalam pengaksesan data base yang digunakan.

3. User diharapkan dapat menjalankan aplikasi ini secara maksimal. 


\section{Daftar Pustaka}

[1] Dewi Kusumawati. Basis Data dengan PostgreSQL. Graha Ilmu; 2015.

[2] Aziz, A, A., 2013, Sistem Informasi Penjualan Berbasis Web Toko Amanah Sebagai Media Peningkatan Citra, STMIK AMIKOM, Yogyakarta.

[3] Tominanto, Waryati, 2013. System Informasi Berbasis Fingerprint untuk Meningkatkan Pelayanan Pasien Rawat Jalan. INFOKES, VOL. 3 No. 2 Agustus 2013.

[4] Gregorius, Agung. 2001. Desain Web Interaktif Dengan Frontpage 2000 dan Dreamweaver 4. Jakarta: PT Elex Media Komputindo.

[5] Haviluddin, 2011. Memahami Penggunaan UML (Unified Modeling Language). Samarinda: Vol 6 No.1. Februari 2011.

[6] Christoper lee. 2014. Tips dan Trik Seleksi Photoshop. Jakarta: PT Elex Media Komputindo. 